\title{
The Profile of High-tech Start-ups: An Approach by the Prism of Graphical Analysis of Network Relations
}

\author{
Diego Rodrigues, José Benedito Sacomano, Nilo Serpa, and Demesio Sousa \\ Paulista University, São Paulo, Brazil \\ \{2drodrigues, jbsacomano, niloserpa, sousamtm\}@gmail.com
}

\begin{abstract}
This study applies two research methodologies, namely literature review and data survey, in order to analyze the behavioral context of contemporary society in its effects on individuals and organizations with regard to the uses of information technology. The behavioral conduct of contemporary society is different in several aspects from that presented in the past, so that new profiles are needed to undertake new business and enterprises. Bearing all this in mind, present paper discusses some important issues such as graphical analysis of the relationships in business networks, innovation, high-tech start-ups, public policies to encourage innovation, business models and their particularities, with a special emphasis in the subject of start-ups
\end{abstract}

Keywords: High-tech start-ups · Social network analysis · Innovation processes $\cdot$ Local development

\section{Theoretical Background}

\section{$1.1 \quad$ Start-ups}

For better understanding of the present study, it is necessary to differentiate the concepts of "start-up" and "spin-off", mainly because of the fact that the first has high level of informality, totally independent of the academic environment, although not necessarily created off this environment. Yet, spin-off is sometimes linked directly to educational institutions, applying in practice the theory learned in classroom or bibliographical research, mostly as proof of concept, with all cognitive tools which the academic environment can offer.

It is important to highlight that, in many situations, start-ups are initially self-employment options for young entrepreneurs, and it is not uncommon the presentation in the media of some cases in which these enterprises are consolidated and become to generate employment, which in general requires high technical knowledge standards.

Nations, organizations and individuals are faced with multiple crises, a fact that aggravates the global climate change, the resource scarcity and the lack of decent employment for about two billion people over the next decade [1]. The environmental impacts caused by outdated models of economy are clear, which 
directly impacts the employment generation, taking into account the young people that shall get positions in the global labor market during the next 10 years. In addition, the extractive model has been the main driver of the current financial crises, alongside the energy and food crisis, causing the social disorders that we are facing with increasing frequency, pointing to the urgent need for a sustainable model [1].

\subsection{Business Model}

Two techniques of business models are widely used in Brazil, with the objective to better present the proposals for accelerators, investors and incubators: the first is the Business Plan, traditionally used by investment companies, banks and investors in rounds of more advanced investments; the second is the BMC (Business Model Canvas), with major representation in the planning of the start-ups; it tends to be the standard used for the selection of enterprisers projects by public policy programs, and instrument that guides the first meetings of entrepreneurs and investors on the most favorable cities to digital entrepreneurships [2].

The Business Model Canvas generation is the result of a creative and cooperative work of 470 entrepreneurs from 45 countries [3]. Ash Maurya [4] proposes an adaptation of the so-called Lean Canvas. This model maintains the basic structure and proposal of the business model generation, but emphasizes specific questions of the niche, such as the main problems to be solved and the "features key" for further product development.

Chiavenato [5] exposes the Business Plan as a set of information that shows the concept of a new venture focusing on marketing, operational and financial perspectives. Its implementation sustains the future entrepreneur to avoid a declining path from enthusiasm to disappointment and failure. Still in accordance to the author, it is also considered as a tool that helps to attract investors, suppliers and partners.

In turn, the BMG was proposed by Osterwalder [6], which after analysis of the business models ontologies came to the conclusion that nine building blocks are enough to have a prior analysis as shown in Table ??.

\subsection{Social Network Analysis}

With regard to the topic "Social Network Analysis", a matter of substantial importance for the development of the work, [7] defines a network as a collection of individuals or organizations linked by various media relations, also points out that a network is composed of nodes and knots. Usually we call "nodes" the actors and they represent individuals or institutions; "knots" in turn represent the relationships between the actors.

According to The Startup Ecosystem 2012 [2], a report of the most favorable environments for the implementation of start-ups based on a geographic indicator, the international ranking comprises the region of São Paulo (Brazil) with position number 13, preceded by Sydney (Australia) which occupies the position 
Table 1. The nine building blocks of business model

\begin{tabular}{|c|c|c|}
\hline Pillar & $\begin{array}{l}\text { Building } \\
\text { Blocks }\end{array}$ & Description \\
\hline Product & $\begin{array}{c}\text { Value } \\
\text { Proposition }\end{array}$ & $\begin{array}{l}\text { The value proposition is an overview } \\
\text { of a company and product packages and } \\
\text { services that add value to the customer. }\end{array}$ \\
\hline \multirow{3}{*}{$\begin{array}{l}\text { Client } \\
\text { Interface }\end{array}$} & $\begin{array}{c}\text { Target } \\
\text { Customer }\end{array}$ & $\begin{array}{l}\text { The target customer is a customer segment } \\
\text { for those who wants to add value. }\end{array}$ \\
\hline & $\begin{array}{c}\text { Distribution } \\
\text { Channel }\end{array}$ & $\begin{array}{l}\text { A distribution channel is a means } \\
\text { of contact with the customer. }\end{array}$ \\
\hline & Relationship & $\begin{array}{l}\text { The relationship describes the type of } \\
\text { connection of a company establishes } \\
\text { between itself and the client. }\end{array}$ \\
\hline \multirow{3}{*}{$\begin{array}{l}\text { Infrastructure } \\
\text { Management }\end{array}$} & $\begin{array}{c}\text { Value } \\
\text { Creation }\end{array}$ & $\begin{array}{l}\text { The value creation describes the arran- } \\
\text { gement of activities and resources that are } \\
\text { needed to generate value for the customer. }\end{array}$ \\
\hline & Capability & $\begin{array}{l}\text { The capability to perform a repetitive } \\
\text { pattern of necessary actions in order } \\
\text { to create value for the customer. }\end{array}$ \\
\hline & Partnership & $\begin{array}{l}\text { The partnership is a cooperation } \\
\text { agreement initiated voluntarily } \\
\text { between two or more companies in order } \\
\text { to create value for the customer. }\end{array}$ \\
\hline \multirow{2}{*}{$\begin{array}{l}\text { Aspect } \\
\text { Financial }\end{array}$} & $\begin{array}{c}\text { Cost } \\
\text { Structure }\end{array}$ & $\begin{array}{l}\text { The cost structure is the representation } \\
\text { of money of all amounts used in the } \\
\text { business model. }\end{array}$ \\
\hline & $\begin{array}{c}\text { Revenue } \\
\text { Model }\end{array}$ & $\begin{array}{l}\text { The revenue model describes how the } \\
\text { company makes money through a variety } \\
\text { of flows revenue. }\end{array}$ \\
\hline
\end{tabular}

number 12; at the top of the list there are Silicon Valley (USA) and Tel Aviv (Israel) occupying the first and second positions respectively.

In addition to the data presented in the report, justifying the listing elaboration and the positioning of the Silicon Valley as a model to be followed, other authors confirm according to the subsequent statements.

- The current Australian public policy relative to the industry of information technology and communication has been strongly influenced by the ideas observed in Silicon Valley [8].

- One of the factors responsible for leading Israel to the top of the global scenario is the human capital [9]. Israel has a high proportion of scientists and engineers as shown in CORDIS [10]. The positive aggressiveness in research and development is due to the fact that the country has 135 engineers and scientists to each 10,000 inhabitants, a significant advantage compared to the US which occupies the second position and has 81 per 10,000.

- Finally, Adams [11] reports the importance of the times when Silicon Valley got an infrastructure of risk capital, from other companies and law firms, 
not only from the academic movement of the 1980s and 1990s, exercising its role as an attractive environment for distant companies in order to win the development and acceleration of start-ups.

\section{Methodology}

For this study, there were applied two research methodologies: literature review and surveys. Specifically, regarding the literature review, this was extremely important to the recognition of the essential variables for the preparation of the questionnaire.

With respect to the format of the questionnaire, it was answered by two different profiles, but complementary to the development of the Brazilian ecosystem of start-ups. The first profile was defined by the experts and supporters of the ecosystem, as investors and professionals linked to supporting organizations to develop companies in Brazil, as well as consultants with experience in public and private policies related to the issue; the second profile are the entrepreneurs in their various skills, some with greater technical knowledge, others with management skills; they are those who had access to specific training or a strong theoretical basis concerning the entrepreneurship issue, as well as the entrepreneurs, who essentially taking decisions based on empirical findings, succeed to participate in a highly selective market in Brazil.

In short, there were two approaches, combining the two research methods: literature review (qualitative) and data survey (quantitative). The association features a mixed method, which was the research method applied [12].

\section{Results and Discussion}

After collecting the data obtained through the questionnaires, it was carried out a verification of data integrity, as well as an indexation, when there were assigned standard values aiming higher performance during the rendering and association among the nodes of the network.

Subsequently for development and better interpretation of the relationships between the actors, it was used the Gephi [13], an open source tool for the analysis and manipulation of representation in networks. In Gephi, the module of display and analysis of social networks and their interactions use a 3D rendering engine for real-time graphics. The same technique is used in the development of video games, where it is used the graphics board of computer providing that the $\mathrm{CPU}$ is available for other computer activities.

For clarity of the graphic result, different colors have been defined for each category of nodes; the categories presented are: (i) Start-ups - their names were not assigned from the questionnaires, so identified by S01 to S73; (ii) Type identified the profile of the representative and the institution, if it was a Startup in fact, or any organization of supporting or investment; There were filled 6 questionnaires with the supporter's profile, the others with the entrepreneurial 
profile; (iii) Gender - of the responsible of the enterprise, in which male entrepreneurs were prevalent, with 68 completed questionnaires; (iv) Representativeness - of the twenty-seven Brazilian Federative Units, from which twelve were registered in the questionnaire; (v) Formal education — of the stakeholders (also registered); (vi) Standard sectors - aligned with the public policy program Start-up Brazil, there were pre-established twelve of them, with an option to open response in the field "Others". Lastly, from the data obtained and used in the development of the work, it was presented category (vii), the current stage of the enterprises. All informed categories are displayed on the left side of the Figure 1.
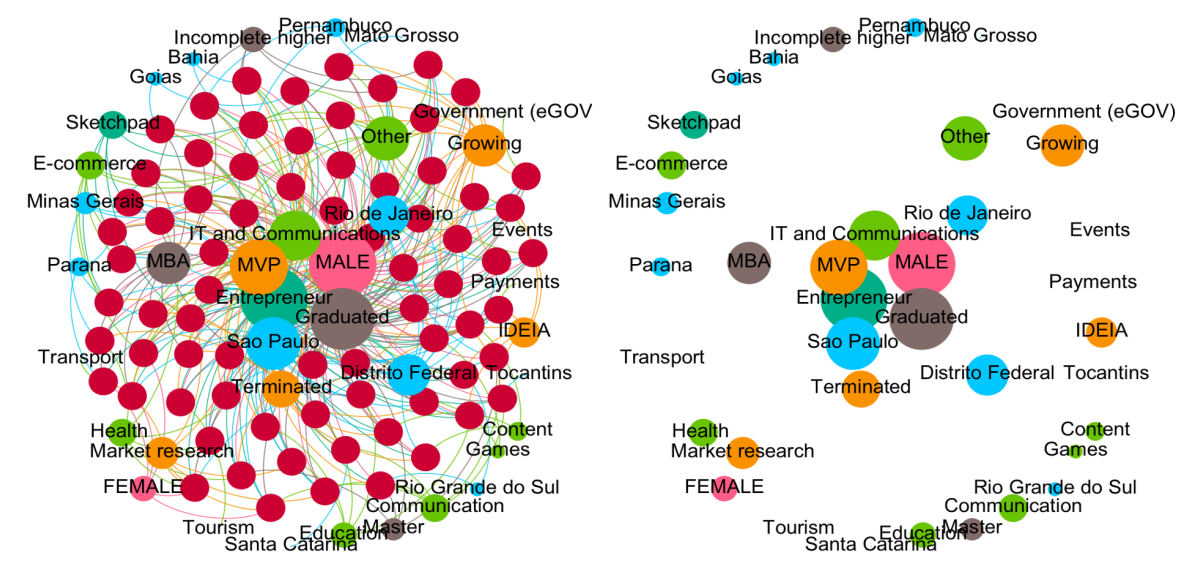

Fig. 1. Network generated with data from the research.

To better understand the representations, the nodes representing the Startups were removed of side b (Figure 1).

It is possible to observe a pattern of spacing and appropriate distribution of network elements. It was applied the algorithm Fruchterman and Reingold [14], where the theoretical form is based on the spring forces (some of the concepts are equivalent to Hooke's law). In the aforementioned data structure there are not only repulsive forces between all nodes, but there are also attractive forces between the adjacent nodes.

In the above picture, it is possible to observe the concept of centrality regarding the categories that are more associated with start-ups in operation.

Even with regard to the centrality it is possible to see the segments with highest rate of associations, where the highlighted is the segment of Information and Communication Technologies.

The Federative Units that presented more projects are also positioned visibly in the network center, being that the Federative Unit of São Paulo is clearly the center of the Figure 1, followed by the state of Rio de Janeiro and then by 
Distrito Federal. Although not displayed in the network center, the Federative Units Minas Gerais and Pernambuco are highlighted by the weight assigned to their respective nodes based on their dimensions.

Regarding the externality of the nodes, it is observed the nodes that represent the female gender, already mentioned, as well as the stages in research and idea representing the enterprises that are not available to their respective customers.

In contrast to previous statements, the following nodes are presented: the male gender, the stage Minimum Viable Product (MVP) and the degree of complete entrepreneur higher education. The respective centrality shows the predominance of the analyzed profiles. With this survey associated with the age and income of the enterprises, it is possible to propitiate new parameters to support strategic decision making.

\section{Conclusions}

Using the methodology proposed in the study, in addition to the contextualization of the issue addressed provided by literature review, it was possible to list the data that allowed a visual analysis of important features of some Start-ups basic network relations.

Objectively, it was demonstrated one of the distinct advantages from graphical analysis of networks, that is, the provision of results in visual form, which in turn provides greater clarity in the interpretation of data.

After the elaboration of the work, in addition to the variables presented, the questionnaire applied raised opinions about the Business Model Canvas blocks. By checking the answers, it was found a considerable level of subjectivity (this is the reason why the data were suppressed from the analysis). Therefore, it is possible to create a demand for the development of a tool to minimize or neutralize the subjectivity indices. Also it was identified, during the development of this article, the existence of sufficient inputs for the implementation of a model to support the modeling of new ventures and the analysis of feasibility of projects.

\section{References}

1. Almeida, F.: Experiências Empresariais em Sustentabilidade. Elsevier Science \& Technology (2009)

2. Marmer, M., Herrmann, B., Dogrultan, E., Berman, R., Eesley, C., Blank, S.: The Startup Ecosystem Report 2012. Tech. rep., Technical report, Startup Genome (2012)

3. Osterwalder, A., Pigneur, Y.: Business Model Generation: A Handbook for Visionaries, Game Changers, and Challengers. Wiley (2013)

4. Maurya, A.: Running Lean: Iterate from Plan A to a Plan that Works. Sebastopol, CA: O'Reilly (2012)

5. Chiavenato, I.: Empreendedorismo: Dando Asas ao Espírito Empreendedor. 3. ed. São Paulo, Brazil. Saraiva (2008)

6. Osterwalder, A.: The Business Model Ontology - A Proposition in a Design Science Approach. Ph.D. thesis, University of Lausanne, Switzerland: 173. 2004 
7. Lazzarini, S.: Empresas em Rede. Cengage Learning, (2008)

8. Mattar, Y.: Post-industrialism and Silicon Valley as Models of Industrial Governance in Australian Public Policy. Telematics and Informatics 25(4), 246-261 (2008)

9. Chorev, S., Anderson, A.R.: Success in Israeli High-tech Start-ups; Critical Factors and Process. Technovation 26(2), 162-174 (2006)

10. CORDIS - Community Research and Development Information Service (2014). Israel's R \& D Capacity - a Promising Land, http://cordis . europa.eu/israel/ rd_en.html

11. Adams, S.B.: Growing where you are Planted: Exogenous Firms and the Seeding of Silicon Valley. Research Policy 40(3), 368-379 (2011)

12. Miguel, P.A.C., Fleury, A., Mello, C., Nakano, D., Turrioni, J., HO, L., Cauchick, P., Morabito, R., Martins, R., Pureza, V., Lima, E.: Metodologia de Pesquisa em Engenharia de Produção e Gestão de Operações, 2E. São Paulo: Elsevier (2012)

13. Bastian, M., Heymann, S., Jacomy, M.: Gephi: An Open Source Software for Exploring and Manipulating Networks. International AAAI Conference on Weblogs and Social Media (2009)

14. Fruchterman, T.M., Reingold, E.M.: Graph Drawing by Force-directed Placement. Software: Practice and experience 21(11), 1129-1164 (1991) 